\title{
THE DESERTED BANK AND THE SPOUSAL EQUITY
}

\section{Mary Welstead}

"... I would fain temper justice with mercy -- justice to the bank, with mercy to the wife..."1

Lord Denning's closing words in National Provincial Bank v. Hastings Car Mart were made in the context of that familiar dispute between a wife in occupation of the mortgaged family home and a bank, in circumstances where the husband had reneged on his mortgage agreement with the bank. $^{2}$

Since then, there has followed a plethora of decisions in which both banks and spouses, alike, hoped that judges would follow Lord Denning's idealism and realise the almost unattainable - a satisfactory outcome for both parties. In the latter part of the 20th century, it is not merely spouses who continue to seek that quality of mercy which Mrs. Ainsworth sought from Lord Denning, but also quasi-spousal partners of both heterosexual and homosexual orientation who occupy the same, mortgaged to the bank, familial home.

Not surprisingly, justice to the bank and mercy to the spouse have remained elusive goals. This is not, merely, because the conflicting parties will almost certainly view the justice and mercy of any given situation in a partisan manner but as the Law Commission has also commented: "The present legal rules are uncertain and difficult to apply and can lead to serious injustice." 3

The accusation of palm tree justice, leveled at Lord Denning's approach

\footnotetext{
* Senior Lecturer in Law, Buckingham Law School, The University of Buckingham.

${ }^{1}$ National Provincial Bank v. Hastings Car Mart [1964] Ch. 665 at 691.

${ }^{2}$ Ibid.

${ }^{3}$ Sixth Programme of Law Reform (Law Com. No. 234). See also [1996] Fam. Law 696 where Charles Harpum, a Law Commissioner is reported as describing, in his address to the 1996 S.P.T.L. Annual Conference, the present law as uncertain, unfair, illogical and that it is not difficult to believe that the Law Commission cannot do better. However, the long awaited consultative document from the Commission has not yet made an appearance. See also Thompson, [1996] 154 Conv. 685.
} 


\section{DENNING LAW JOURNAL}

in National Provincial Bank v. Hastings Car Mart, has been viewed as an accurate assessment of much judicial thinking in this area of law. ${ }^{4}$

Certain key decisions between 1970 and 1995 permit a cogent analysis of the means by which the courts have attempted to develop equitable principles relating to the resolution of claims to beneficial interests in family homes. The decisions appear to veer between judicial adherence to a strict interpretation of the rules, primarily based on the concept of the constructive trust, and a creative judicial manipulation of those same rules, in a manner more akin to proprietary estoppel. The perceived justice and mercy of any given situation would appear to determine, or be determined by, judicial interpretation of the concept. A strict legal interpretation of the principles tends to benefit lending institutions in that the familial partner is liable to be denied a right, which would bind third parties. By contrast, the creative estoppel based approach would appear to assist familial partners in acquiring a proprietary right. ${ }^{5}$

It must, however, be questioned whether either of these approaches have resulted in anything other than a continued lack of realism with regard to familial arrangements, on the one hand, and a scant respect for the economic realities of lending institutions on the other. The decisions have left both banks and the non-borrowing familial partner with a residue of uncertainty and considerable legal expenditure.

Any starting point for the analysis of the evolution and expansion of the constructive trust doctrine in this context must commence with the decision in Gissing v. Gissing. ${ }^{6}$ Here, the House of Lords attempted to give a definitive formulation of the elements required to ground a constructive trust of the family home. The language used by Lord Diplock is remarkably similar to that of proprietary estoppel. He accepted that such a trust is created.

"...by a transaction between the trustee and the cestui que trust in connection with the acquisition by the trustee of a legal estate in land, whenever the trustee has so conducted himself that it would be inequitable to allow him to deny to

\footnotetext{
${ }^{4}$ In National Provincial Bank v. Hastings Car Mart Lord Denning M.R maintained that "...it is the way of English law to decide particular cases and then seek for the principle..." See also e.g. Springette v. Defoe [1992] 2 F.L.R 388, in which Dillon L.J. asserted that: "The court does not as yet sit, as under a palm tree, to exercise a general discretion to do what the man in the street, on a general overview of the case might regard as fair..."[at p.393].

${ }^{5}$ The conflict between banks and family members is primarily confined to the context of secondary borrowing. In circumstances where the initial purchase of the property has been made by way of loan, the bank will normally take priority following the decision in Abbey National v. Cann [1991] 1 A.C. 56; see also Bristol \& West Building Society v. Henning [1985] 1 W.L.R. 778.

${ }^{6}[1971]$ A.C. 886.
} 
the cestui que trust a beneficial interest in the land acquired. And he will be held to have so conducted himself if by his words or conduct he has induced the cestui que trust to act to his own detriment in the reasonable belief that by so acting he was acquiring a beneficial interest in the land."?

Lord Diplock drew the distinction between two types of transactions, which, in his opinion, would give rise to a trust of the beneficial interest. In the first type of transaction there is an express agreement that the parties should share the beneficial interest in the property. The person without legal title must then proceed to do some act to facilitate the property's acquisition. Such an act may take the form of a contribution to the purchase price or the deposit or the mortgage payments or "make some other material sacrifice by way of contribution to or economy in the general family expenditure." ${ }^{.8}$ According to Lord Diplock, the beneficial shares are to be calculated in accordance with the express agreement of the parties.'

Is Lord Diplock's definition of this first type of transaction anything other than a slight variation of the doctrine of proprietary estoppel? It will be recalled that the canonical view of this doctrine is that it arises in circumstances where one party has been encouraged by the legal titleholder to alter her position to her detriment in the expectation of some entitlement in the property concerned. ${ }^{10}$ The ensuing equity will be satisfied in whatever way the court deems to be appropriate, taking into account all the circumstances of the case. ${ }^{11}$ In Lord Diplock's first category of constructive trust the expectation of the claimant is more specific; it relates to a share of the beneficial interest. His explication of the associated detrimental reliance is more restrictive; it must be of a direct or indirect financial nature. Finally, his approach to the quantification of the share is confined to the nature of the express agreement rather than allowing the court complete discretion.

In the second type of transaction, described by Lord Diplock, there is no express agreement to share the beneficial interest in the property. If the

\footnotetext{
${ }^{7}$ Ibid at p.905.

${ }^{8}$ Ibid.

${ }^{9}$ Ibid.

${ }^{10}$ See e.g. Dillwyn v. Llewelyn (1862) 4 De G.F \& J. 517, 45 E.R 1285; Ramsden v. Dyson (1866) L.R. 1 H.L. 129; Willmott v. Barber (1880) 15 Ch. D. 96; Taylors Fashions Ltd. v. Liverpool Victoria Trustees Co. Ltd. [1982] 1 Q.B. 133; Pascoe v. Tumer [1979] 2 All E.R. 945; Re Basham [1986] 1 All E.R. 405; Matharu v. Matharu [1994] 2 F.L.R. 597.

${ }^{11}$ See Plimmer v. Mayor etc. of Wellington (1884) 9 App. Cas. 699 at 714; Crabb v. Arun D.C. [1976] Ch.179 at 189; Griffiths v. Williams (1977) 248 E.G. 947 at 949.
} 
parties have not applied their minds in any way to the issue, the court may not impute an agreement to them. ${ }^{12}$ However, they:

"...may well have formed a common intention that the beneficial interest in the land shall be vested in them jointly without having used express words to communicate this intention to one another; or their recollections or the words used may be imperfect or conflicting by the time any dispute arises."

In those circumstances the parties' intentions to share the beneficial interest, and the subsequent quantification of that interest, may be objectively inferred from their words or conduct on the basis of the reasonable man test. ${ }^{14}$ Lord Diplock proceeded to outline those limited circumstances from which the court would infer a relevant intention. Where the claimant's actions are confined to direct financial contributions to the outright purchase price of the property or to the initial deposit or legal expenses and nothing more, a resulting trust would normally arise. ${ }^{15}$ The quantification of the claimant's beneficial share would clearly be inferred in direct proportion to the level of her financial contribution. However, Lord Diplock acknowledged that where the family home was purchased by way of mortgage loan, to limit the quantification of the beneficial share to a consideration of the initial contribution would be to ignore economic and social reality. He, therefore, extended the resulting trust principle and accepted that post acquisition conduct on the part of the claimant could also lead to an inference of an intention to share the beneficial interest, or of an intention to enhance the initial share if contributions to the purchase price or legal costs had already been made. In this context, Lord Diplock differentiated between direct and indirect contributions. He explained that direct contributions to the mortgage payments would lead to the inference of either intention. Indirect payments towards the mortgage payments, by way of financial contribution to general household expenditure which would otherwise be met by the mortgagor so as to enable him to make the mortgage payments, would only be taken into account to give the claimant an enhanced share. ${ }^{16}$ Thus indirect contributions will be of no avail in those situations where a mortgage loan of one hundred per cent of the value of the

\footnotetext{
${ }^{12}$ Gissing v. Gissing supra n.6 at 906.

${ }^{13}$ Ibid.

${ }^{14}$ Ibid.

${ }^{15}$ See e.g. Dyer v. Dyer (1788) 2 Cox. Eq.Cas. 92 at 93, 30 E.R. 42 at 43 ; Pettit v. Pettit [1970] A.C. 777 at 814; Cowcher v. Cowcher [1972] 1 W.L.R. 425 at 431.

${ }^{16}$ Gissing v. Gissing supra n.6 at p.907ff.
} 
property has been granted or where the claimant has made no initial contribution to the legal costs, and the mortgagor demonstrates an ability to finance both the mortgage payments and the general household expenditure. $^{17}$

Given Lord Diplock's empathetic appreciation of the social reality of familial behaviour, ${ }^{18}$ his differentiation between direct and indirect contributions seems excessively legalistic, as does his failure to take into account domestic contribution in inferring the relevant intention. ${ }^{19}$

By contrast, in determining quantification in the second type of transaction, Lord Diplock declined to base it solely on the parties' respective financial contributions to the mortgage payments, both direct and indirect. He accepted that the court must do its utmost to discover, if necessary by inference from conduct, the likely common understanding of the parties vis-a-vis their respective shares even though such an understanding might not have been expressly stated or even consciously formulated in words by either party. In the case of contributions to mortgage installments over a period of many years the level of the parties' contributions from their individual income is likely to change in accordance with the "the varying exigencies of family life to be expected during the period of repayment." ${ }^{20}$ For instance, the wife might have to forego earning money outside the home in order to take care of children and it might be possible to infer that their common intention at the time of acquisition of the familial home was that the beneficial interest should be held by them in equal shares and that each should contribute to the cost of its acquisition whatever amount each could afford at a given time. If, however, a subsequent reduction in mortgage payments is not attributable to a reduction in earnings due to motherhood or some other cause from which the man benefits as well, it might seem a more likely inference that the beneficial interest should be less than equal.

Lord Diplock decided that it may even be possible to infer that, on acquisition, the parties made no agreement to quantify their respective shares but would wait until a later date such as the end of the mortgage period or sale and do so on the basis of their total respective direct and indirect financial input.

If there is no evidence from which an inference with respect to quantification can be drawn, Lord Diplock concluded that, the court might have to apply as a rule of law, rather than an inference of fact, the maxim "equality is equity" and grant an equal share of the beneficial interest to

\footnotetext{
${ }^{17}$ See e.g. Burns v. Burns [1984] I All E.R. 244.

${ }^{18}$ Gissing v. Gissing supra n.6 at p.906.

${ }^{19} \mathrm{Cf}$. the approach of the Canadian courts, Welstead, "Domestic Contribution and Constructive Trusts: the Canadian Perspective" [1987] Denning L.J. 151.

${ }^{20}$ Gissing v. Gissing supra n.6 at p.909.
} 
both partners.

These conclusions seems close to fulfilling the belief that "palm tree justice" rules in this area of law and a betrayal of the court's purported sincere belief that both the intention to confer a beneficial interest on the claimant and the quantification of that interest may only be inferred and not imputed. If there is no other evidence, it is difficult to see how the application of the equitable maxim of equality can ever be a more appropriate approach than inferring quantification from the party's respective financial contributions.

For many years after Gissing, the case law on constructive trusts of the family home was forced into two neat categories based on Lord Diplock's view of the two forms of agreement. Those family litigants, who could coerce their circumstances into evidencing an explicit agreement, tended to succeed in acquiring an equitable interest in the family home. Once they were able to show such an agreement, the nature of the detrimental reliance required was less onerous than for claimants maintaining an inferred agreement. These first category of claimants could claim as relevant detriment not merely direct financial contributions towards the property but also indirect financial contributions whether or not they had made any initial contribution to the property and regardless of the mortgagor's ability to repay the loan without this indirect financial contribution. Substantial physical work on the property could also be claimed as a detriment.

Cooke v. Head, is illustrative of this first type of agreement. ${ }^{21}$ The parties were cohabiting; they found land on which they decided to build a bungalow, title to which was in the sole name of the man. The property was funded by way of mortgage loan. He had, however, declared that the property was:

"....as much hers as it is mine...She has equal rights to it. She has put as much into that bungalow as I have."22

The female claimant carried out considerable physical work to the building of the property. The Court of Appeal accepted that a constructive trust had arisen on the basis of an express agreement followed by some other material sacrifice involving contribution to or economy in the general family expenditure. However, the court departed from the Gissing approach, which based quantification in these circumstances on the explicit agreement. Lord Denning moved even closer to the estoppel principle and chose to exercise the court's discretion and take into account

${ }^{21}$ [1972] 2 All E.R. 38.

22 Ibid at p.42. 
all the circumstances of the case. The court proceeded to award the claimant one third of the value of the property in spite of the clear intention evidenced by the man's statement that they were to share it equally. ${ }^{23} \mathrm{~A}$ further example of the manner in which claimants have attempted to force their circumstances within the ambit of an explicit agreement is to be found in Eves v. Eves. ${ }^{24}$ Here, the sole legal titleholder, Mr. Eves, had began to live with the claimant, a young woman aged nineteen. She took his name and gave birth to two children during their short relationship of four years. Mr. Eves had told her that he was buying a house for both of them and their children but that he could not put the house in joint names as she was under twenty-one; this was of course merely a devious ploy on his part. Mrs. Eves did substantial renovation work on the property including the wielding of a sledgehammer.

Lord Denning accepted that the man's statement was an explicit indication of his intention to share the beneficial interest in the property with the claimant. The Court of Appeal exercised its discretion and awarded the claimant one quarter of the equity in the property but without explanation how quantification had been reached. Once again it must be assumed that the discretionary principles of estoppel were used to determine quantification, particularly in the light of Lord Denning's view that as the claimant had remarried, "this share would I hope be regarded by her as more in the nature of provision for the children than for her.",25

Few claimants have been fortunate enough to be able to bring the haphazard nature of their familial arrangements within the categorisation of so-called explicit agreements. They have been forced, with little success, to attempt to widen the category of payments, outlined in the second category of transaction in Gissing, from which a relevant intention to share the beneficial interest might be inferred.

In Burns v. Burns, for example, a long term female cohabitant had made no initial contribution to the purchase price or legal costs of acquiring the property but had made generous financial contributions to household expenditure ${ }^{26}$ She argued that such contributions should equally give rise to an inference of a relevant intention to share the beneficial interest as they would had she made a financial contribution to the deposit or legal costs.

The Court of Appeal rejected this argument. Perhaps it was influenced in its view by the fact that the claimant's partner maintained that he was able to fund the mortgage payments without her help. In spite of his benefiting in a more general way by her financial contributions to the

\footnotetext{
${ }^{23}$ Wachtel v. Wachtel [1973] 1 All E.R. 829.

${ }^{24}$ [1975] 3 All. E.R. 768.

${ }^{25}$ Ibid at p.772.

${ }^{26}$ Supra n.17 at p.252; see also Hayton, [1990] Conv. 370.
} 


\section{DENNING LAW JOURNAL}

household, she was deemed to be simply generous spirited rather than allowing the quasi-matrimonial home of nineteen years to be acquired. May L.J. acknowledged that:

" over a very substantial number of years she may have worked just as hard as the man in maintaining the family, in the sense of keeping house, giving birth to and looking after and helping to bring up the children of the union., 27

The Court of Appeal accepted that the outcome of its rigid application of the Gissing principles left the claimant in a difficult and harsh situation but that it was for Parliament and not the courts to redress any perceived injustice.

Some two years later, however, in Grant v. Edwards, there were signs of an increasing awareness of a change in familial arrangements and social expectations and that it was perhaps up to the courts to address the problems in an equitable, rather than an excessively legalistic, manner. ${ }^{28}$ Here, the female claimant had cohabited with the defendant in the family home, title to which was in his sole name. The defendant told her that her name would not be put on the title because it might prejudice the outcome of divorce proceedings between the claimant and her husband. This, according to the Court of Appeal was not so much an explicit agreement, but rather raised the distinct inference that there was a clear understanding between the parties that they were to share the beneficial interest in the house. Otherwise no excuse for not putting her name onto the title would have been needed. ${ }^{29}$ The court also accepted the fact that insurance monies received after a fire damaged the property were paid into a joint account was further evidence of an inferred agreement to share the beneficial interest.

This approach suggests a merging of the two categories of agreements outlined in Gissing and an extension of the type of behaviour, which might give rise to the inference of an implicit relevant agreement. ${ }^{30}$ Subsequently the woman had made substantial payments towards general household expenses and housekeeping. The man could not have made the mortgage payments had she not done so.

In Grant v, Edwards, Browne-Wilkinson V.-C. explained that where the

\footnotetext{
${ }^{27}$ Ibid at p.264ff.

${ }^{28}$ [1986] 2 All E.R. 426.

29 Ibid at p.433.

${ }^{30}$ Waite L.J. in Midland Bank v. Cooke [1995] 4 All E.R. 562, suggested, at 573, that Grant v. Edwards was a decision based on the doctrine of proprietary estoppel rather the doctrine of constructive trusts. See also the comments of Browne-Wilkinson V.-C. in Constructive Trusts and Unjust Enrichment (Holdsworth Club of the University of Birmingham, 1991).
} 
claimant had proven an explicit agreement or an inferred agreement (albeit on the basis of a wider category of behaviour than discussed in Gissing), prima facie, the interest of the claimant will be that which the parties intended. However, he suggested that:
"...the law of proprietary estoppel may again provide useful guidance. If proprietary estoppel is established, the court may give effect to it by giving effect to the common intention so far as may fairly be done between the parties. For that purpose equity is at its most flexible.... Identifiable contributions to the purchase of the house will of course be an important factor in many cases. But in other cases, contributions by way of labour or other unquantifiable actions of the claimant will also be relevant.",31

The principles of constructive trusts and proprietary estoppel appear to have been elided ${ }^{32}$ thus leaving open the way for a more realistic evaluation of all familial behaviour in determining the satisfaction of the claim and not merely the parties' intentions with respect to the direct or indirect financial contributions referable to the acquisition of the property.

Although there was a brief return to the rigid dual categorisation of agreements in Lloyds Bank v. Rosset, ${ }^{33}$ the trend towards a more benevolent approach to familial arrangements prevailed in Midland Bank v. Cooke ${ }^{34}$ Waite L.J., in a judgment, more social than legal in content, acknowledged the uncertainties and difficulties in interpreting and applying the rules surrounding the concept of the constructive trust. He demonstrated his awareness that home ownership has become socially and economically significant and almost totally dependent on loans from mortgagee banks.

In 1971, Mrs. Cooke, the second defendant, had contributed $£ 500$ towards the purchase price of the family home. The money came from her share of a wedding present from her husband's parents. The balance of the purchase price had been provided by way of mortgage loan of $£ 6,540$ from a building society and $f 1,000$ from the husband's personal savings. There was no explicit agreement between Mrs. Cooke and her husband that she should have a beneficial share in the family home. Indeed, both she and her husband said that they had no recollection of discussing at the time of acquisition the precise arrangements in relation to the house; they

\footnotetext{
${ }^{31}$ Grant v. Edwards [1986] supra n.28 at p.439; see also Eekelaar, [1987] Conv.93.; BrowneWilkinson V.-C. ibid.

${ }^{32}$ Hayton, [1993] 109 L.Q.R. 485.

${ }^{33}$ [1990] 1 All E.R. 1111.

${ }^{34}$ [1995] 4 All E.R. 563.
} 


\section{DENNING LAW JOURNAL}

were simply happy at setting up home together.

Mrs. Cooke made no direct payments towards the mortgage payments from her income but did pay for general household expenditure. There was no evidence that these payments had enabled her husband to make the mortgage payments. She had also engaged in work on the property and garden in the form of redecoration, alterations, improvements and repairs.

The judge at first instance held that the wife had acquired a beneficial interest of 6.47 per cent behind a resulting trust, based on her minimal financial contribution to the purchase price. He rejected any inference of an agreement that her share should be enlarged because of her subsequent indirect financial contributions and improvements to the property. Waite L.J. acknowledged:
"the difficulties which these cases pose for the honest recollections of witnesses and the barrenness of the terrain in which judges and district judges who try them are required to search for the small evidential nuggets on which issues as to the existence -or the proportions- of beneficial interest are liable to depend."35

Whilst conceding that he was bound by the decision in Gissing, Waite L.J.'s dicta suggest a merging of the two categories of express and implied agreements, particularly with respect to quantification. He stated that once the relevant intention to found a beneficial interest came into existence either by way of an express agreement or by inference, the duty of the judge is:

" ... to undertake a survey of the whole course of dealing between the parties relevant to their ownership and occupation of the property and their sharing of its burdens and advantages. That scrutiny will not confine itself to the limited range of acts of direct contribution of the sort that are needed to found a beneficial interest in the first place. It will take into consideration all conduct, which throws light on the question what shares were intended. Only if that search proves inconclusive does the court fall back on the maxim that "equality is equity." 36

\footnotetext{
${ }^{35}$ Ibid at p.567.

${ }^{36}$ Cf. Springette v. Defoe supra n.4, in which Dillon L.J. declined to grant an enhanced share to the claimant. He maintained that the presumption of resulting trust based on the claimant's initial contribution should not be displaced where there was no evidence of an agreement as to how the parties would share the beneficial interest. See also McHardy \& Sons (a firm) v.

Warren [1994] 2 F.L.R. 338 in which Dillon L.J. took the opposite approach and declared that
} 
Waite L.J. accepted that the majority of young people agree to set up joint homes in a spirit of mutual trust and hope of a permanent relationship and do not concern themselves with legalistic matters relating to the quantification of beneficial shares in their family home should they decide to part at some uncertain point in the future. To do so would be a contradiction of that trust and hope.

In his attempt to quantify the defendant's share of the beneficial interest, Waite L.J. recognised, inter alia, the significance of her child care and career as a teacher, her signature to consent forms accepting joint and several liability for loans for the husband's business, ${ }^{37}$ her home maintenance and improvements. ${ }^{38}$ Furthermore he acknowledged for the first time in English law, in the context of constructive trusts, the additional fact "...that this was a couple who had chosen to introduce into their relationship the additional commitment which marriage involves..."

He concluded that the inferred intention of the husband and wife was to share the beneficial interest in equal shares.

There appears to be a very short judicial step from taking into account all the circumstances of family life for the purposes of quantification of the familial partners' beneficial shares in the home, to taking them into account for the purposes of inferring the relevant intention and detrimental reliance to ground an intention to share the beneficial interest in the first instance. Such an approach suggests a merging of the doctrines of proprietary estoppel and constructive trusts.

However admirable the efforts of the judiciary to understand the nature of familial relationships and, thereby, ultimately escape the rigid, unreal search for the elusive common intention, is it fair to grant an equitable interest which has the potential, as an overriding interest, to bind banks which lend on the security of the family home? $?^{40}$ Waite L.J. acknowledged in Midland Bank v. Cooke that in the joint venture of a relationship the parties share the benefits and burdens of financial success and failure. If the discretionary approach of the judiciary continues it seems increasingly likely that it will be banks who bear the burden of

the parties held the beneficial interest equally even though there was no evidence of how the parties intended to hold their shares.

${ }^{37}$ It would seem that Mrs. Cooke was remarkably fortunate; it was held at first instance that her consent was obtained by undue influence and the bank could not benefit by her consent yet her consent was viewed in a positive way in quantifying her interest.

${ }_{38}^{38}$ See also Hammond v. Mitchell [1991] 1 W.L.R.1127; Drake v. Whipp [1996] 1 F.L.R. 826

${ }^{39}$ Midland Bank v. Cooke supra n. 30.

${ }^{40}$ In the absence of overreaching, (see e.g. City of London Building Society v. Flegg [1988]

A.C.54), s.70 (1)(g) of the Land Registration Act 1925 governs the priorities in registered land (see e.g. Williams \& Glyn's Bank v. Boland [1981] A.C. 487) whilst the doctrine of notice has a similar effect in unregistered land, (see e.g. Kingsnorth Trust v. Tizard [1986] 2 All E.R.54). 
financial failure rather than members of the family. ${ }^{41}$

They will not only have to find out whether there are additional members of the family living in the about-to-be-mortgaged property but they will also have to examine all the past and present circumstances of the familial entourage before deciding whether to lend or not.

Banks are commercial organisations governed, inter alia, by duties to their shareholders and clients, both borrowers and lenders. There is an inherent tension between lending money to purchasers of family homes, and doing so in a manner, which safeguards commercial interests. This tension must be acknowledged. Protecting homeowners rather than banks may seem socially desirable but ultimately it is homeowners who will pay the price in terms of higher borrowing costs. A totally new approach to the problems experienced by lending banks and family members, at each other's hands, is required if the present judicial manipulation of concepts is to be discontinued. ${ }^{42}$ Solutions appropriate for intra-familial disputes are not often appropriate for disputes between banks and members of families. ${ }^{43}$

One possible solution to the former type of dispute would be an explicit acceptance of the judicial merging of the doctrines of proprietary estoppel and constructive trusts. Once an expectation followed by a detrimental reliance is established, an inchoate right will arise. The right will only crystallise once the court has granted a discretionary remedy, which may include the grant of a constructive trust, based on all the circumstances of the case. ${ }^{44}$ Because the right dates from the time of the court hearing it will not bind third parties. The process would not be dissimilar to the courts' approach to the division of matrimonial assets on divorce. ${ }^{45}$

Banks lending money require greater certainty. They have already been forced into setting up elaborate mechanisms to deal with the problems of familial partners who, having waived their equitable rights, seek to rely on

\footnotetext{
${ }^{41}$ See Reid, "The Legal Implications of Williams \& Glyn's Bank v. Boland" in Gower, Problems of Conflict of Interest in the Matrimonial Home (1981) at p.24.

${ }^{42}$ See [1996] Fam. Law 696 where a Law Commissioner, Charles Harpum is reported as having suggested four possible solutions to the difficulties; a twofold approach which would combine a more precisely defined intention based constructive trust coupled with an adjustive regime; a totally adjustive regime; a property law regime based on rules defining length of relationship, the existence of children, and direct economic contributions and finally, the encouragement of explicit agreements between family members which would be required to be registered at the Land Registry. He concluded that there are "...no perfect solutions, merely least awful ones."

${ }^{43}$ See Browne-Wilkinson V.-C., supra n.30.

${ }^{44}$ See e.g. the comments of Lord Denning M.R. in Hussey v. Palmer [1972] 3 All E.R. 744 at 748; In re Basham (decd.) supra n.10 at p.1504; Pearce v. Pearce [1977] 1 N.S.W.L.R. 170.

${ }^{45}$ See Matrimonial Causes Act 1975 s.25.
} 


\section{THE DESERTED BANK AND THE SPOUSAL EQUITY}

the doctrine of undue influence. ${ }^{46}$ Nevertheless, they remain at risk of discovering an overriding interest under section 70(1)(g) of the Land Registration Act 1925 in circumstances where it would have been possible to have knowledge of the owner of that interest. Has the time arrived for the abolition of such overriding interests? ${ }^{47}$ The 1925 legislators, clearly, did not envisage the rise in constructive trusts and the consequent increase in claimants of overriding interests some seventy years later. Familial partners may already register their equitable proprietary rights as minor interests. ${ }^{48}$ Why should they be given a second chance of pleading an overriding interest?

It has been frequently argued that family members do not register their informally obtained rights because registration appears as an aggressive act towards the legal titleholder and would destroy the mutual trust and hope between the parties that their relationship will endure and not require legal protection. ${ }^{49}$ This is; however, a paternalistic approach, which attempts to protect family members in times of economic misfortune without the acknowledgement that they, not infrequently, obtain, benefits from their partners who borrow in times of economic success. ${ }^{50}$ They should be positively encouraged to register their rights. Once it becomes accepted common behaviour to register rights or risk their loss for lack of registration, it will cease to be regarded as a hostile act. ${ }^{51}$

If paternalism is accepted as an appropriate vehicle for the protection of the family home, it may equally require recognition that the family home is an inappropriate asset for the purpose of securing borrowings other than for the initial purchase of the property itself. In those circumstances new legislation might be enacted which would designate family homes as safe havens for those who live there as members of the same family. ${ }^{52}$ Inherent in such legislation would be rules governing the use of the family home as security to obtain further borrowings. Family members would indeed be

\footnotetext{
${ }^{46}$ See e.g. Barclays Bank v. O'Brien [1994] 1 A.C. 180; Bank of Credit \& Commercial Intemational v. Aboody [1990] 1 Q.B. 923; C.I.B.C. v. Pitt [1994] 1 A.C. 200; Midland Bank v. Greene [1994] 2 F.L.R. 827.

${ }^{47}$ See Law Commission, Property Law:Second Report on Land Registration (Law Com. No. 158, 31st March, 1987, para 2.7.)

${ }^{48}$ Land Registration Act 1925 s.3(xv).

${ }^{49}$ See the comments of Waite L.J. in Midland Bank v. Cooke supra n.34 at p.575; see also Hayton, supra n.26 at p.387.

${ }^{50}$ See the comments of Waite L.J. in Midland Bank v. Cooke supra n.34 at p.575.

${ }^{51}$ See Kantorowicz (1937) 53 L.Q.R. 326; see also (1984) 272 E.G. 1295.

${ }^{52}$ A possible model for such legislation could be ss.62 \& 63 of the Family Law Act 1996 which define a wide variety of familial relationships deemed worthy of protection by way of occupation orders in the family home. See also the Joint Family Homes Act 1964 which was enacted in New Zealand to grant limited protection, against creditors, to those familial members who have settled their family home under the act.
} 


\section{DENNING LAW JOURNAL}

truly protected and would have to find other means of borrowing to fund all those ventures which are currently dependent on remortgaging the family home.

Until a satisfactory statutory solution is reached in resolving the tension between social justice for family members and protection of the economic interests of lending banks, the ideological struggle between "mercy for the wife and justice for the bank" will remain reflected in judicial interpretation of the doctrine of constructive trusts. 